\title{
INTERIM DEVELOPMENT REPORT: ENGINEERING-SCALE HTGR FUEL PARTICLE CRUSHER
}

by

J. W. BAER and J. B. STRAND

\author{
Prepared under \\ Contract EY-76-C-03-0167 \\ Project Agreement No. 53 \\ for the San Francisco Operations Office \\ Department of Energy
}

DATE PUBLISHED: SEPTEMBER 1978 


\title{
NOTICE
}

This report was prepared as an account of work sponsored by the United States Government Neither the United States nor the Department of Energy, nor any of their employees, nor any of their contractors, subcontractors, or their employees, makes any warranty, express or implied, or assumes any legal liability or responsibility for the accuracy, completeness or usefulness of any information, apparatus, product or process disclosed, or represents that its use would not infringe privately owned rights

\author{
Printed in the United States of America \\ Avallable from \\ National Technical Information Service \\ U. S. Department of Commerce \\ 5285 Port Royal Road \\ Springfield, Virginia 22161 \\ Price: Printed Copy $\$ 4.50$; Microfiche $\$ 3.00$
}




\section{DISCLAIMER}

This report was prepared as an account of work sponsored by an agency of the United States Government. Neither the United States Government nor any agency Thereof, nor any of their employees, makes any warranty, express or implied, or assumes any legal liability or responsibility for the accuracy, completeness, or usefulness of any information, apparatus, product, or process disclosed, or represents that its use would not infringe privately owned rights. Reference herein to any specific commercial product, process, or service by trade name, trademark, manufacturer, or otherwise does not necessarily constitute or imply its endorsement, recommendation, or favoring by the United States Government or any agency thereof. The views and opinions of authors expressed herein do not necessarily state or reflect those of the United States Government or any agency thereof. 


\section{DISCLAIMER}

Portions of this document may be illegible in electronic image products. Images are produced from the best available original document. 


\title{
INTERIM DEVELOPMENT REPORT: ENGINEERING-SCALE HTGR FUEL PARTICLE CRUSHER
}

\author{
by
}

J. W. BAER and J. B. STRAND

\author{
Prepared under \\ Contract EY-76-C-03-0167 \\ Project Agreement No. 53 \\ for the San Francisco Operations Office \\ Department of Energy

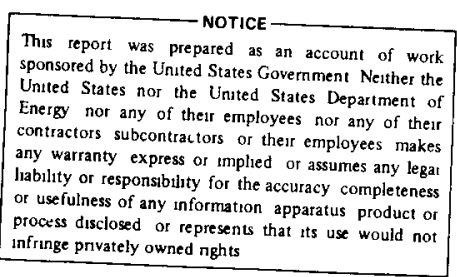 \\ GENERAL ATOMIC PROJECT 3261 \\ DATE PUBLISHED: SEPTEMBER 1978
}

\section{GENERAL ATOMIC COMPANY}




\begin{abstract}
During the reprocessing of HTGR fuel, a double-roll crusher is used to fracture the silicon carbide coatings on the fuel particles. This report describes the development of the roll crusher used for crushing Fort-St.-Vrain type fissile and fertile fuel particles, and large hightemperature gas-cooled reactor (LHTGR) fissile fuel particles. Recommendations are made for design improvements and further testing.
\end{abstract}


,

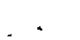

$\because$

.

\author{
.
}

. 
ABSTRACT . . . . . . . . . . . . . . . . . . . . iii

SUMMARY . . . . . . . . . . . . . . . . . . v vi1

1. INTRODUCTION . . . . . . . . . . . . . . . . . 1

2. REQUIREMENTS . . . . . . . . . . . . . . . . . . . 3

3. EQUIPMENT DESCRIPTION . . . . . . . . . . . . . . . . 5

4. FSV FERTILE PARTICLE CRUSHING . . . . . . . . . . . . . . 9

5. FSV FISSILE PARTICLE CRUSHING . . . . . . . . . . . 20

5.1. Developmental Testing ............... 22

5.2. Demonstration of LHTGR WAR fissile fuel particle crushing ..................... 27

5.3. Crusher Operation - Sequential Burn . . . . . . . 29

6. CRUSHER DRIVES AND BEARINGS . . . . . . . . . . . . . . . 31

7. ROLL WEAR . . . . . . . . . . . . . . . . . . . 34

8. FUTURE PLANS . . . . . . . . . . . . . . . . . . . . 36

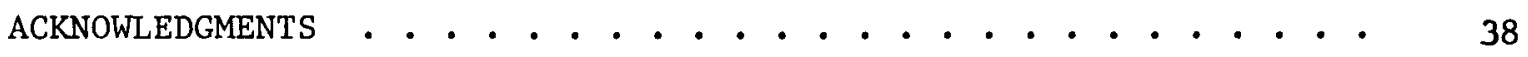

REFERENCES . . . . . . . . . . . . . . . . . . . . 39

\section{FIGURES}

1. Fuel particle crusher and drive motor (mounted on secondary burner feed hopper) . . . . . . . . . . . . . 6

2. Double-roll particle crusher . . . . . . . . . . . . 7

3. Fuel particle crusher product size distributions for various throughput rates.................... 10

4. Fuel particle crusher product size distributions for various roll gaps . . . . . . . . . . . . . . . . . . .

5. Particle crusher side plate showing wear groove after $150 \mathrm{~kg}$ of throughput . . . . . . . . . . . . . 15

6. Fertile crusher side body with tungsten carbide insert . . . . 17

7. Effect of flame hardening on process control and production control specimens . . . . . . . . . . . . . . . 


\section{FIGURES (Continued)}

8. Feed and product size distributions, FSV fissile particle crusher . . . . . . . . . . . . . . . . . . .

9. Preload torque and solder thickness versus shim thickness, roll 5211011-13, s/N 4340-5 ............... 24

10. Preload torque and solder thickness versus shim thickness, roll 5211011-10, S/N 4340-2 .............. 25

11. Size distributions, crushed WAR particles . . . . . . . . 28

12. Size distribution of feed and product from sequential operation using $0.20-\mathrm{m}$ secondary burner . . . . . . . . . 
The reprocessing of HTGR fuels will involve use of a double-roll crusher to crush the TRISO coated fuel particles. This allows subsequent combustion in a fluidized-bed burner, which removes the inner carbon coatings and converts the metal carbides to oxides.

Experimental work was performed with two double-roll crushers that were identical except for the roll sizes, which determine the crushing gap. Satisfactory fracturing of the silicon carbide coatings of Fort St. Vrain (FSV) and large high-temperature gas-cooled reactor (LHTGR) TRISO fuel particles was demonstrated. The following observations and recommendations are offered as a result of the initial testing:

1. Fuel particle crushing can be accomplished within acceptable burner feed requirements using a nonadjustable roll gap in a disposable crusher module.

2. Side plate wear is more severe than roll wear, and occurs at a higher rate than anticipated.

3. Ro11 bearings must be protected from crushing dusts by use of high performance seals or barrier systems. These methods and others that will keep debris away from the roll bearings should be examined and tested.

4. Rol1 bearing preloads are vital to maintaining precise roll gaps. Excessive preloads are detrimental to bearing life. 
5. The double-roll particle crusher is sensitive to tolerances during manufacture and assembly. A simpler, advanced design that separates bearing loading from the frame is recommended.

6. Crushing of silicon carbide or an equally abrasive material should continue until roll wear trends can be established. 


\section{INTRODUCTION}

Using unirradiated fuels, General Atomic Company is developing a high-temperature gas-cooled reactor (HTGR) fuel reprocessing pilot plant. This work is a part of the National HTGR Fuel Recycle Development Program, under the direction of the Department of Energy. The overall objective of the program is to demonstrate the technology for recycling HTGR fuels by using the Th/U-233 fuel cycle for future safe operation of a commercial plant.

Equipment and process demonstrations will be done in the cold pilot plant to obtain data for the design and operation of an HTGR reference recycle facility (HRRF). The pilot plant systems include the dry head-end processes, in which:

1. Fuel elements are reduced in size by crushing.

2. Element and matrix graphites are removed by combustion in a fluidized bed.

3. Fissile and fertile particles are separated by pneumatic classification.

4. The silicon carbide coatings of the TRISO fuel particles are broken in a crusher.

5. The inner carbon coatings are removed, and the metal oxycarbides are converted to oxides by combustion in a fluidized bed.

The fissionable materials are recovered in the wet head-end processes, then refabricated into fuel. 
This report describes the tests done on the engineering-scale fuel particle crusher to date.

Fuel particles enter the crusher by gravity flow from its feed bunker. The crushing action is produced from contact between the surfaces of two counter-rotating rolls and the fuel particles. This forces the particles through a narrow gap between the rolls. The gap is precisely set for each type of particle so that the silicon carbide coating is broken without overcrushing. This produces a product that is easily fluidized in the burner. The crushed particles gravity flow into the burner feed hopper.

Testing to date has included determination of (1) throughput rates, (2) start-under-load capabilities, (3) product size distributions, (4) roll gap requirements, and (5) quantity of unbroken particles. Fissile and fertile FSV fuel particles and LHTGR TRISO fissile particles have a11 been successfu11y crushed. 


\section{REQUIREMENTS}

The reprocessing of HTGR fuel requires the fracture of the outer silicon carbide coating of fuel particles to expose the inner carbon coatings and carbides for fluidized-bed combustion.

The fuel particle crusher mủst accept carbide-coated fuel and must crack but not crush the carbide she11s. It provides the secondary burner feed with a minimum size distribution of approximately $160 \mu \mathrm{m}$ volume-tosurface diameter at a rate of at least $30 \mathrm{~kg}$ per hour from $60 \mathrm{~kg}$ batches. This is to be accomplished safely in a semicontinuous fashion in compact, long-life equipment that can be readily maintained or replaced when the limit of $1 \%$ unbroken fuel particles is exceeded. The equipment must start when fully loaded and operate in the environment of a hot cell.

Detailed requirements for the equipment may be found in Ref. 1 .

Test objectives of the test program as defined in Ref. 2 were to validate the equipment to meet the design, performance, material safeguard, health, and safety requirements and to determine the suitability of the fixed gap, double-roll crusher for a hot reprocessing facility. Testing was accomplished in three phases:

\footnotetext{
Phase I - Demonstration of roll crusher with FSV-type fertile fuel particles

Phase II - Demonstration of roll crusher with FSV-type fissile fuel particles

Phase III - Demonstration of roll crusher with LHTGR-type fissile fuel particles
} 
Preoperational testing was performed to determine proper roll gaps and appropriate roll bearing preloads to maintain the roll gap.

Additional ongoing testing is achieved while the equipment is operated to provide feed material for the testing of the secondary burner and for head-end sequential burns. 


\section{EQUIPMENT DESCRIPTION}

The fuel particle crusher is a small, compact, double-roll crusher with a fixed crushing gap. The crushing rolls are $10 \mathrm{~cm}$ (4 in.) in diameter by $10 \mathrm{~cm}$ ( 4 in.) long, and they are made of hardened steel. It operates semicontinuously in-line with the solids handling system to produce feed for the secondary burner. Figure 1 shows the fuel particle crusher and drive motor mounted in place on the secondary burner hopper. The double-roll fuel particle crusher, shown schematically in Fig. 2, is described in detail in Ref. 1.

Fuel particles enter the fuel particle roll crusher by gravity flow from the particle crusher feed bunker. The crushing action is produced by the contact between the two counter-rotating roll surfaces and the fuel particles, which forces the fuel particles through the narrow gap between the rolls. The crushed fuel particles are discharged by gravity into the secondary burner feed hopper. The 10-cm (4-in.) diameter rolls, driven by a variable-speed drive system, are contained in an enclosure that connects the crushing system to the particle crusher feed bunker and the secondary burner feed hopper. This enclosure prevents loss of fuel particles, fragments, and dust. The configuration of the rolls and the enclosure assembly precisely determines the crushing gap between the rolls and assures that all of the fuel particles will pass through the roll gap. The roll gap can only be altered by replacing the rolls with rolls of different diameters.

In normal crusher operation, the drive motor is activated, the drive controller is set for the desired roll rpm (read on a speed indicator), and the rolls are allowed to reach the desired speed. The fuel particles are batch-charged by opening a knife gate valve in the discharge outlet of the particle crusher feed bunker; they are choke-fed by gravity to the 


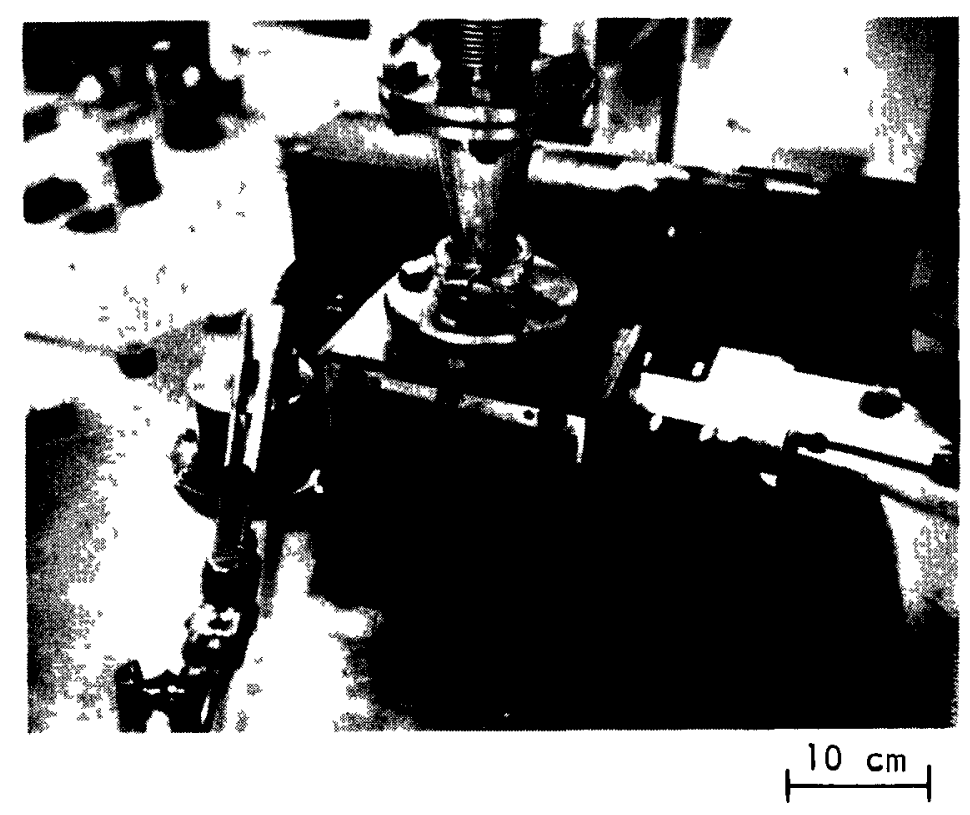

Fig. 1. Fuel particle crusher and drive motor (mounted on secondary burner feed hopper) 


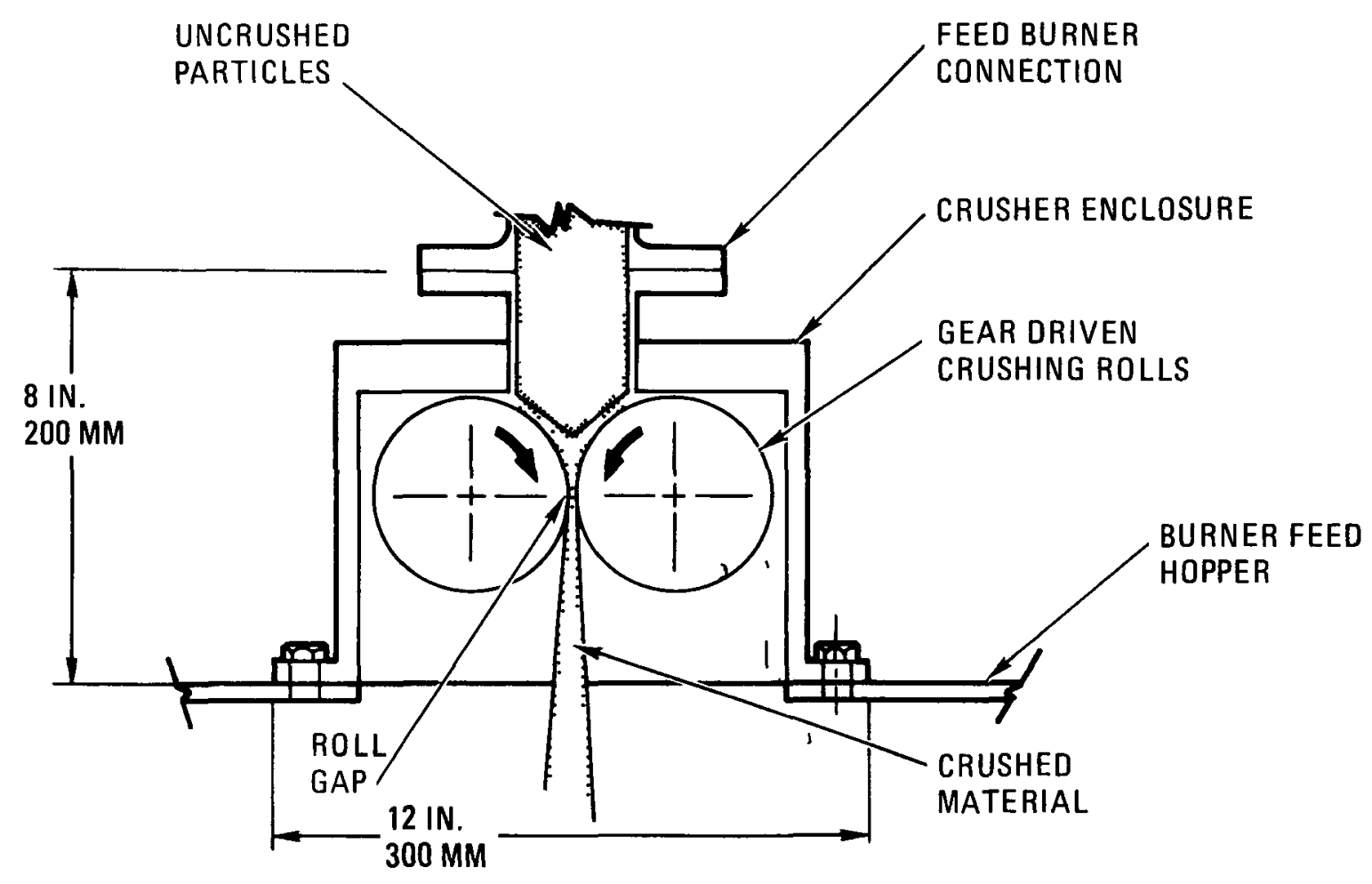

Fig. 2. Double-roll particle crusher 
crushing area, where the silicon carbide coatings of the particles are fractured. The crushed material is then discharged into the burner feed bunker. 


\section{FSV FERTILE PARTICLE CRUSHING}

This particle crusher, which is driven by a $560-\mathrm{W}$ ( $3 / 4 \mathrm{hp}$ ), variablespeed dc electric motor with a 40:1 reducer, has demonstrated the ability of a double-roll crusher to successfully process FSV fertile and fissile fuel particles. It is fully operational, and it has been used in the preparation of feed material for the secondary burner. The following discussion summarizes its development activities to date.

Phase I of the activity plan (Ref. 2) for the fuel particle crusher was completed successfully, demonstrating the ability of the double-roll crusher to process FSV fertile fuel particles. Tests were performed utilizing representative feed lots split from a single larger lot. The tests were arranged so that actual crusher performance could be compared with the performance requirements of the particle crusher design criteria (Ref. 3). A comparison of the individual performance requirements of the design criteria with the actual test results is given below.

The double-roll crusher was required to process fuel particles at a minimum rate of $30 \mathrm{~kg} / \mathrm{h}$. Tests proved the throughput rate to have a linear relationship with roll speed. Throughput rates of 50, 101, and 148 $\mathrm{kg} / \mathrm{h}$ resulted from roll speeds of 25,50 , and $72 \mathrm{rpm}$. In each case, the product size distributions were virtually identical (see Fig. 3) even though the throughput rates varied by factors of two and three.

If the double-roll crusher is shut down during operation, it must have sufficient power to be restarted without removing the feed material remaining in the crusher. Several tests were performed with feed material in the crusher prior to startup. No significant differences were observed in crusher starting characteristics or in product size distribution for the two load cases. 


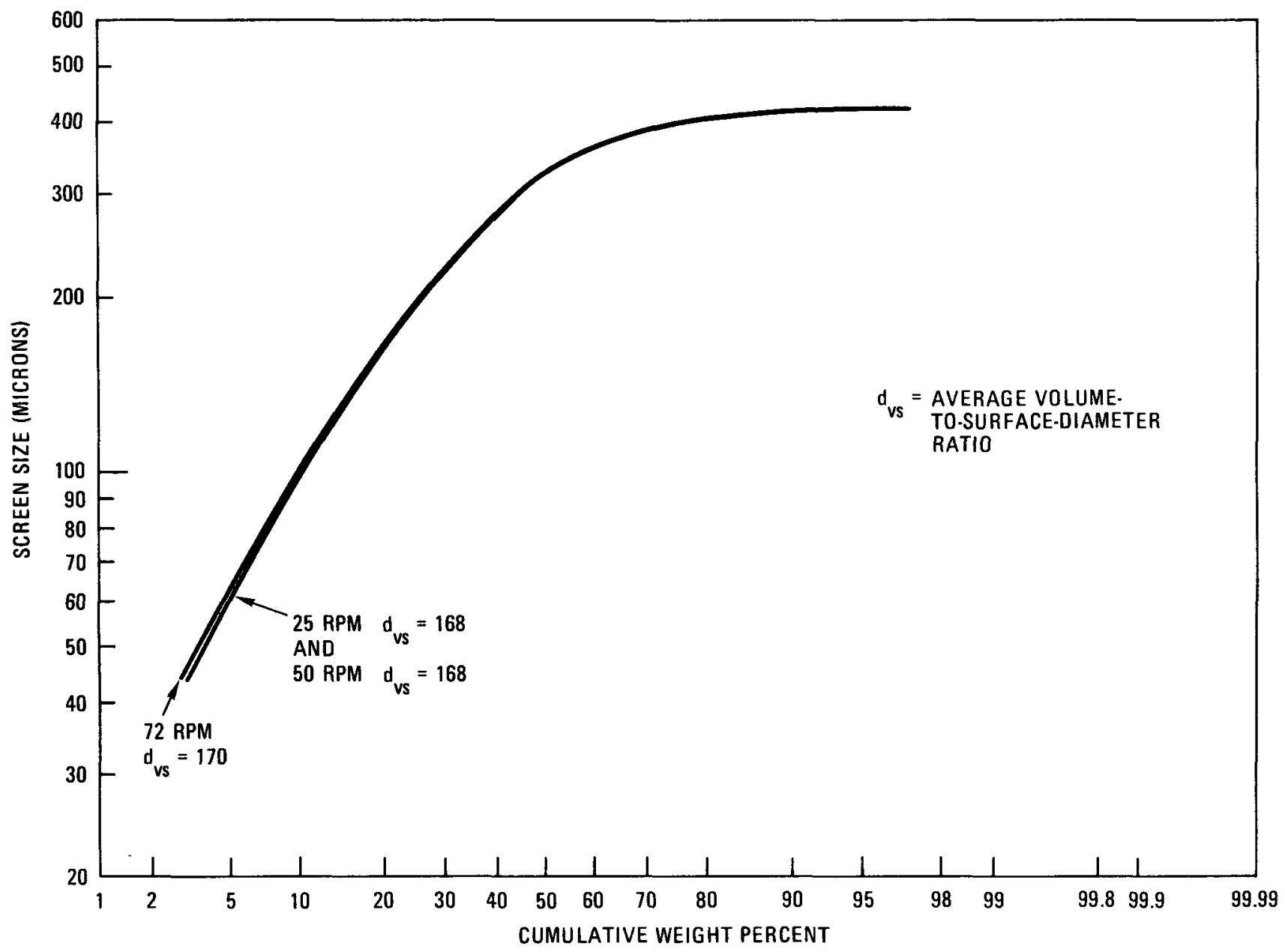

Fig. 3. Fuel particle crusher product size distributions for various throughput rates 
The crusher product must contain less than $1 \%$ unbroken particles. Throughout the test program, unbroken particles were found in small quantities in the upper two size categories $(>500 \mu \mathrm{m}$ and $>425 \mu \mathrm{m})$. The maximum amount of unbroken particles found in all the tests was estimated at less than $0.1 \%$.

The size distribution requirement for the crusher product is $160 \mu \mathrm{m}$ minimum volume-to-surface diameter. To describe usefully the size distribution of a batch of solid particles, the size distribution functions $P$ and $\mathrm{p}$ were defined as follows (Ref. 4). Let $\mathrm{P}$ be the volume fraction (or weight fraction or numbers fraction) of particles smaller than size $d_{p}$ and let $\mathrm{pd}\left(\mathrm{d}_{\mathrm{p}}\right)$ be the volume fraction (or weight fraction or numbers fraction) of particles of size between $d_{p}$ and $d_{p}+d\left(d_{p}\right) . P$ gives the cumulative distribution of sizes and is dimensionless, while $p$ gives the distribution directly and has units of reciprocal length.

The relationship between $\mathrm{p}$ and $\mathrm{P}$ is found by considering particles of any particular size $\mathrm{d}_{\mathrm{p}_{1}}$, for which

$$
p_{1}=\left(\frac{d P}{d\left(d_{p}\right)}\right)_{1} \text { or } \quad p_{1}=\int_{0}^{d_{1}} \operatorname{pd}\left(d_{p}\right) \text {. }
$$

For discrete distribution of particles with equal or unequal intervals of size (sieve analysis produces a discrete distribution of unequal size intervals), the relation between $p$ and $P$ at any $d_{p_{i}}$ is

$$
p_{i}=\left(\frac{\Delta p}{\Delta d_{p}}\right)_{i} \quad \text { or } \quad p_{i}=\sum^{i}\left(p \Delta d_{p}\right)_{i}=\sum^{i} x_{i}
$$

where $x_{i}$ is the fraction of material in size interval $i$.

With the size distribution of particles defined, the specific surface and mean diameter of a mixture of different-sized particles of a given shape may be found. For pressure drops in flow through beds (a variable 
in secondary burner fluidization), the surface area of the particles is the prime consideration. Thus, mean sizes and shapes are defined such that for a given mass of solid, the surface area remains constant. Using the size distribution, the mean specific surface is defined as

$$
\bar{a}^{-}=\sum^{a 11} a_{i}{ }^{\prime}\left(p \Delta d_{p_{i}}\right)_{i}=\frac{6}{\phi_{s}} \sum^{a 11} \frac{i}{d_{p_{i}}}=\frac{6}{\phi_{s}} \sum^{a 11}\left(\frac{x}{d_{p}}\right)_{i}
$$

for a discrete distribution. Since the mean specific surface defined in terms of mean diameter is

$$
\overline{\mathrm{a}}-\frac{6}{\phi_{\mathrm{s}} \overline{\mathrm{d}}_{\mathrm{p}}},
$$

the mean diameter becomes

$$
\bar{d}_{p}=\frac{6}{\phi_{s} \vec{a}^{\prime}}=\frac{1}{\sum^{a}{ }^{i}\left[\left(p \Delta d_{p}\right)_{i} / d_{p_{i}}\right]}=\frac{1}{\sum^{a 11}\left(x / d_{p}\right)_{i}} .
$$

For mixtures of particles of different sizes and shapes, $\bar{d}_{p}$ and $d_{p}$ are replaced by $\overline{\phi_{s} d_{p}}$ and $\phi_{s} d_{p}$, respectively. Since the shape factors $\left(\phi_{s}\right)$ are unknown in our size distribution, the shape factors are assigned the value of unity for ease of calculation. The mean diameter $\left(\bar{d}_{p}\right)$ is termed the volume-to-surface diameter $\left(d_{v s}\right)$ since the surface area is the prime consideration. A description of how the equation for the volume-to-surface diameter,

$$
\mathrm{d}_{\mathrm{vs}}=\frac{1}{\sum\left(\frac{\mathrm{x}}{\mathrm{d}}\right)},
$$

is used for a given particle batch is given in Ref. 5 .

The main objective of the Phase I tests was to determine the roll gap at which the product size distribution meets the $160-\mu \mathrm{m}$ requirement. The proper roll gap was approached from the low side at 25.4- $\mu$ m (0.001-in.) 
intervals. The final three tests at a roll gap of $480 \mu \mathrm{m}(0.019 \mathrm{in}$. produced volume-surface diameters greater than $160 \mu \mathrm{m}$. At successively smaller roll gaps, smaller volume-surface diameters were obtained. Figure 4 shows the product size distributions for various roll gaps.

The roll gap selected for crushing the Fort St. Vrain fertile fuel particles was $480 \mu \mathrm{m}$ (0.019 in.).

Upon completion of the Phase I testing of the fertile particle crusher (and after processing approximately $150 \mathrm{~kg}$ of FSV fertile fuel particles), it was found that the amount of unbroken fuel particles had risen from $<1 \%$ to $>2 \%$ by weight. The allowance for unbroken particles was established by Ref. 3 at $<1 \%$ by weight for secondary burner feed.

The crusher was disassembled to determine the reason for this increase in unbroken fuel particles. No apparent evidence of wear on the roll crushing surfaces or on the roll ends was found, and there was no evidence of spalling, gouging, or galling on any wearing surface. However, each side body plate showed extensive erosive wear in the region opposite the crushing region at the ends of the roll pairs (see Fig. 5). The wear pattern was a groove approximately $0.3 \mathrm{~mm}$ (0.012 in.) deep by $0.6 \mathrm{~mm}$ (0.025 in.) wide by $7.9 \mathrm{~mm}(0.3 i \mathrm{in.})$ long in each side plate. Two grooves of this size and a roll gap of $0.48 \mathrm{~mm}(0.019 \mathrm{in.})$ would be sufficient to pass uncrushed fuel particles 0.51 to $0.56 \mathrm{~mm}(0.020$ to 0.022 in.) in diameter. This would account for approximately $2 \%$ unbroken particles.

The wear grooves were filled with a ceramic coating material, chromium oxide, which was applied to the wear area by plasma spraying. This material has an equivalent hardness of $R_{C} 74$ compared with the side plate hardness of $R_{c} 57$ and the roll hardness of $R_{c} 58$. There was no local reduction in side plate hardness resulting from the plasma spray coating application. 


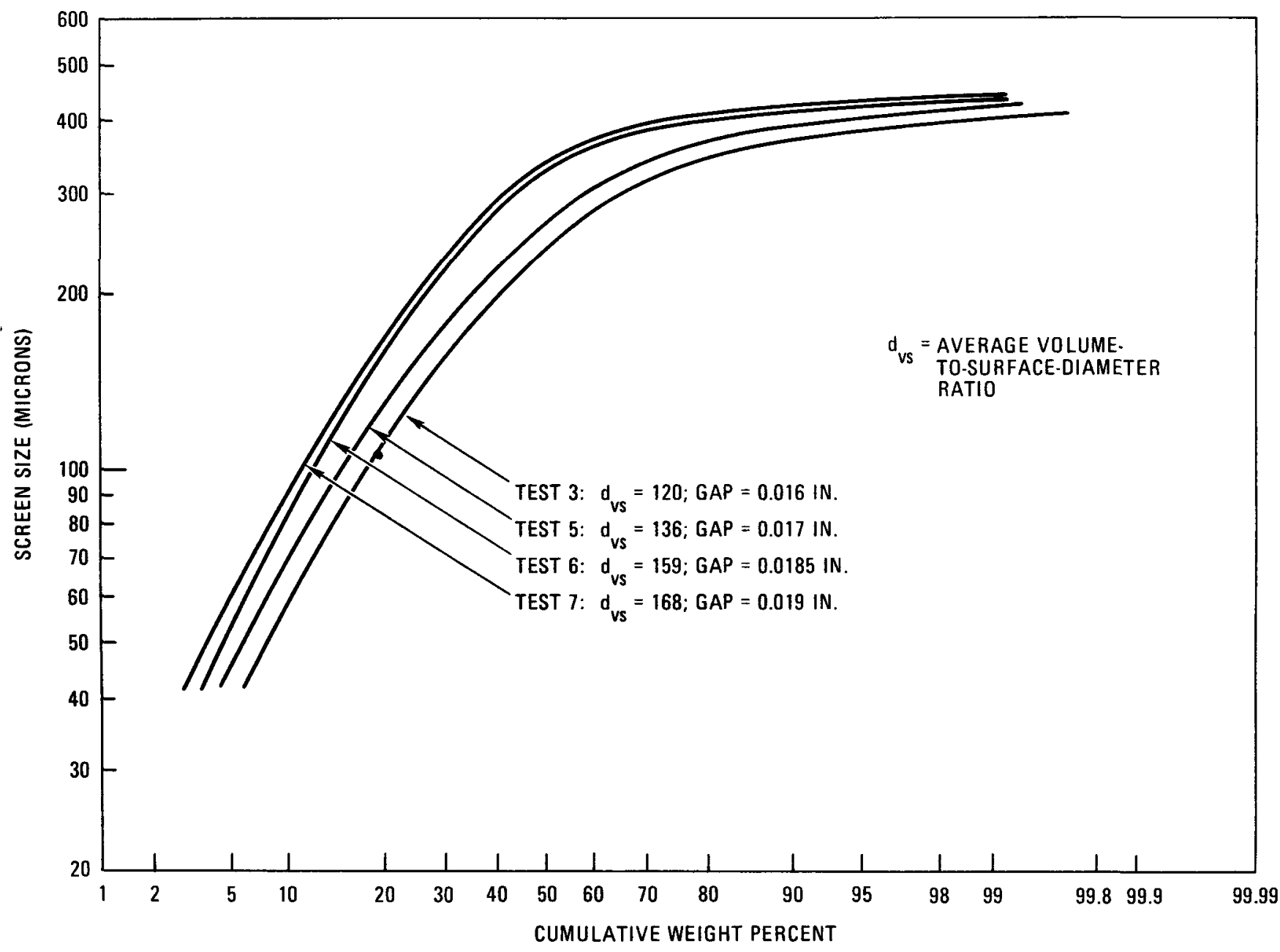

Fig. 4. Fuel particle crusher product size distributions for various roll gaps 


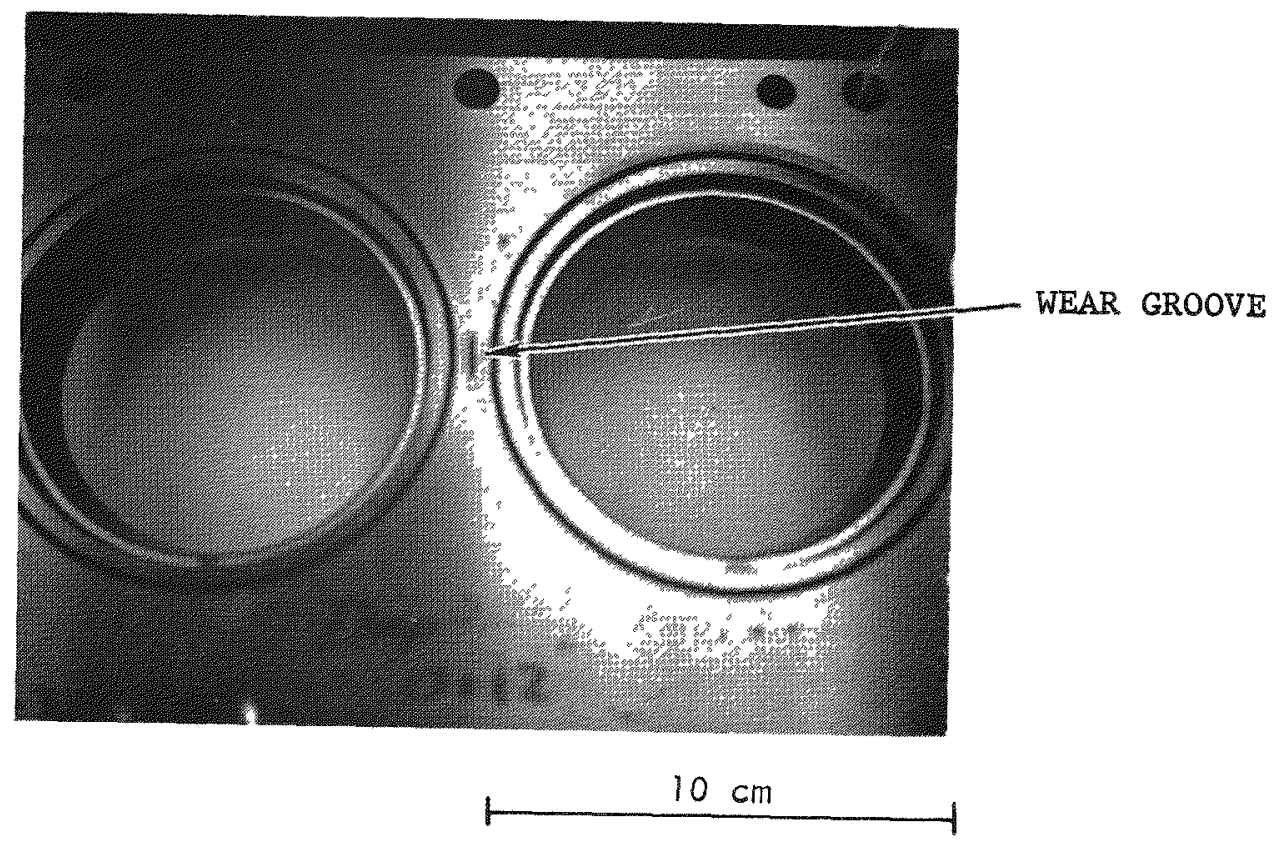
Fig. 5. Particle crusher side plate showing wear groove after $150 \mathrm{~kg}$
of throughput 
After crushing one $60 \mathrm{~kg}$ batch of fuel particles, this ceramic chromium oxide coating wore excessively, and a tungsten carbide sprayed coating was tried. It, too, was unsuccessful when a $60 \mathrm{~kg}$ batch was crushed.

The side bodies were next slotted by electrical discharge machining (EDM), and inserts of high-density, cemented tungsten carbide were embedded in the slots. Each side plate contained a different candidate insert material for comparative evaluation purposes. These materials have hardnesses typically equivalent to $R_{c} 80$ to 83 , as compared with the plasma-sprayed chromium oxide at $R_{c} 74$ and the tungsten carbide composites at $R_{c} 60$ to 70. One side plate with the tungsten carbide insert is shown in Fig. 6.

The FSV fertile particle crusher was then used to prepare feed for four burner runs on the $0.20-\mathrm{m}$ secondary burner. The total throughput was $240 \mathrm{~kg}$. The roll gap setting was $480 \mu \mathrm{m}$, and the roll speed was between 36 and $44 \mathrm{rpm}$. The crushing efficiency was $>99.9 \%$ for each run.

The localized wear on the crusher body side plates continued. The inserts of tungsten carbide composites $\mathrm{K} 703$ and $\mathrm{K} 68$ were tested simultaneously, crushing $150 \mathrm{~kg}$ of material. Both tungsten carbide inserts exhibited improved wear resistance, with the $\mathrm{K} 703$ proving to be the better material.

The $\mathrm{K} 68$ insert was removed and replaced with a solid ceramic material, boron carbide $\left(\mathrm{B}_{4} \mathrm{C}\right)$, which has outstanding hardness (2750 Knoop) compared with tungsten carbide (1800 Knoop). Particle crushing continued with the crusher equipped with the new $\mathrm{B}_{4} \mathrm{C}$ insert and retaining the previously installed $\mathrm{K} 703$ insert for continued wear information. There has been little evidence of additional wear to either insert since crushing was restarted.

Table 1 1ists the various test materials used in the crusher body side plates and gives the wear test results obtained from crushing siliconcarbide-coated fuel particles. 


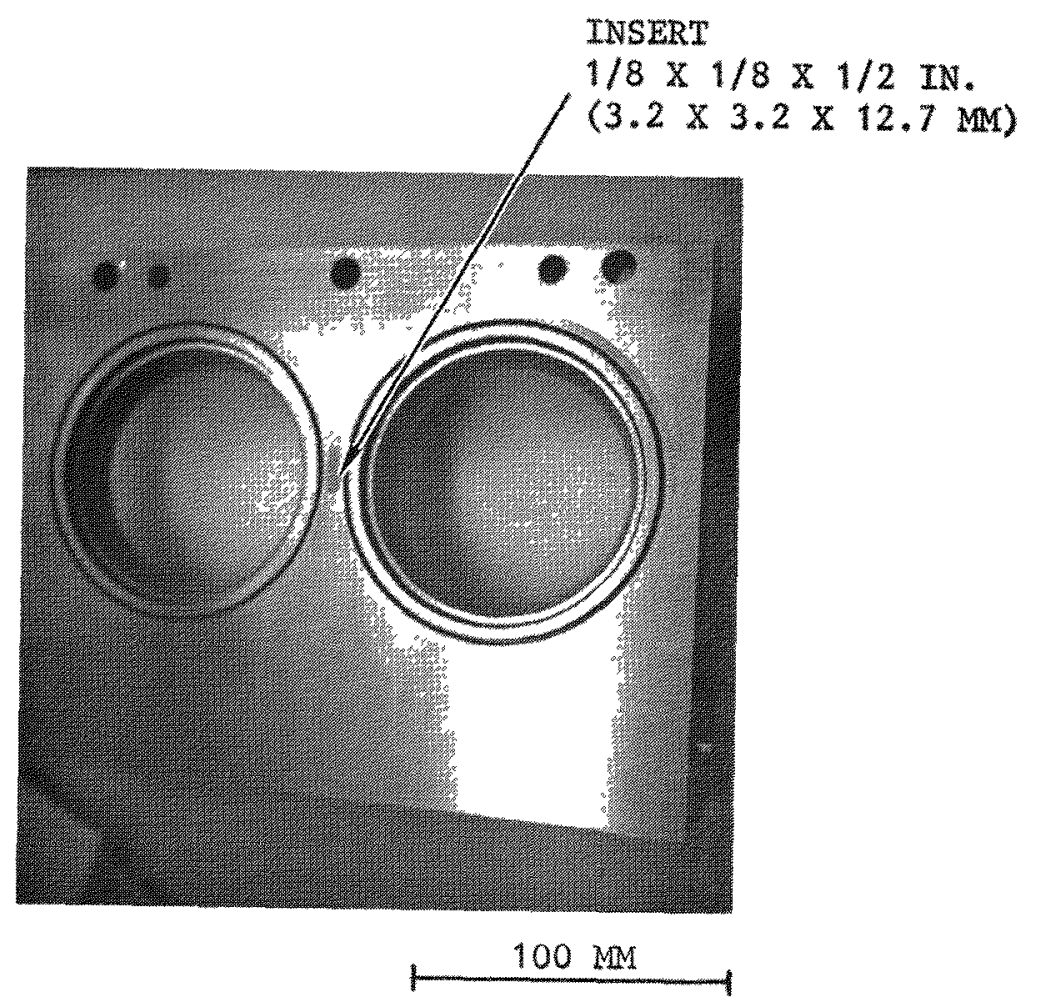

Fig. 6. Fertile crusher side body with tungsten carbide insert 
TABLE 1

SIDE BODY WEAR DATA, FERTILE PARTICLE CRUSHER

\begin{tabular}{|c|c|c|c|c|c|c|c|}
\hline \multirow[b]{2}{*}{ Material } & \multirow{2}{*}{$\begin{array}{l}\text { Source } \\
\text { and Type }\end{array}$} & \multicolumn{2}{|c|}{ Hardness (a) } & \multirow{2}{*}{$\begin{array}{c}\text { Abrasion } \\
\text { Resistance (b) }\end{array}$} & \multirow[b]{2}{*}{ Observed Wear } & \multirow{2}{*}{$\begin{array}{c}\text { Crusher } \\
\text { Throughput }\end{array}$} & \multirow[b]{2}{*}{ Comments } \\
\hline & & $\mathrm{R}_{\mathrm{C}}$ & $\mathrm{R}_{\mathrm{A}}$ & & & & \\
\hline Tool steel & AISI D2 & 57 & 79 & 13 to 14 & $\begin{array}{l}\text { Slot, } 0.3 \mathrm{~mm}(0.012 \mathrm{in.}) \\
\text { deep } \times 0.6 \mathrm{~mm}(0.025 \mathrm{in.}) \\
\text { wide }\end{array}$ & $150 \mathrm{~kg}$ & As designed \\
\hline $\begin{array}{l}\text { Chromium oxide, } \\
\text { plasma spray }\end{array}$ & $\begin{array}{l}\text { Metco } \\
136 \mathrm{~F} \text { - repair }\end{array}$ & 74 & 89 & Unknown & $100 \%$ removed & $60 \mathrm{~kg}$ & No binder \\
\hline $\begin{array}{l}\text { Tungsten carbide, } \\
\text { plasma spray }\end{array}$ & $\begin{array}{l}\text { Metco } \\
73 \mathrm{~F} \text { - rapair }\end{array}$ & 60 & 81 & Unknown & $>90 \%$ removed & $60 \mathrm{~kg}$ & $\begin{array}{l}\text { Best plasma spray } \\
\text { product - cobalt binder }\end{array}$ \\
\hline $\begin{array}{l}\text { Tungsten carbide, } \\
\text { plasma spray }\end{array}$ & $\begin{array}{l}\text { Metco } \\
\text { 71VF - repair }\end{array}$ & 53 & 78 & Unknown & $100 \%$ removed & & $\begin{array}{l}\text { Comparison material - } \\
\text { cobalt binder }\end{array}$ \\
\hline $\begin{array}{l}\text { Tungsten carbide, } \\
\text { and chromium } \\
\text { oxide, solid } \\
\text { ceramic }\end{array}$ & $\begin{array}{l}\text { Kennametal } \\
\text { K703 - insert }\end{array}$ & 80 & 92 & 760 & $\begin{array}{l}\text { Slot, } 0.1 \mathrm{~mm}(0.0044 \mathrm{in.}) \\
\text { deep } \times 0.6 \mathrm{~mm}(0.055 \mathrm{in.}) \\
\text { wide }\end{array}$ & $150 \mathrm{~kg}$ & $\begin{array}{l}\text { Cobalt binder, best } \\
\text { composite material }\end{array}$ \\
\hline $\begin{array}{l}\text { Tungsten carbide, } \\
\text { solid ceramic }\end{array}$ & $\begin{array}{l}\text { Kennametal } \\
\text { K68 - insert }\end{array}$ & $>80$ & 93 & 300 & $\begin{array}{l}\text { Slot, } 0.2 \mathrm{~mm}(0.0073 \mathrm{in.}) \\
\text { deep } \times 0.7 \mathrm{~mm}(0.028 \mathrm{in.}) \\
\text { wide }\end{array}$ & & Cobalt binder \\
\hline $\begin{array}{l}\text { Boron carbide, } \\
\text { solid ceramic }\end{array}$ & $\begin{array}{l}\text { Norton Co. } \\
\mathrm{B}_{4} \mathrm{C} \text { insert }\end{array}$ & 2750 & oop $(c)$ & Unknown (d) & Traces, (e) not measured & $180 \mathrm{~kg}$ & None \\
\hline
\end{tabular}

(a) From vendor data, except D2 tool steel which was hardness tested.

(b) Abrasion resistance equals unity divided by volume loss with dry silica sand - Kennametal data.

(c) For comparison, solid tungsten carbide $=1880 \mathrm{Knoop}$ and solid silicon carbide $=2480 \mathrm{Knoop}$.

(d) Material used in sand blast nozzles.

(e) Product continues to be acceptable after crushing. 
The boron carbide $\left(\mathrm{B}_{4} \mathrm{C}\right)$ insert implanted in one side plate in the region of highly localized wear was closely examined after $180 \mathrm{~kg}$ of particles were crushed. The surface of the insert appeared to be burnished in a characteristic pattern, but the wear was not measured. The other insert of $\mathrm{K} 703$ material did not show evidence of any measurable additional wear. 


\section{FSV FISSILE PARTICLE CRUSHING}

The pilot plant experimental plan also called for the development of a crusher to remove the SiC coatings from the FSV fissile fuel kernels. The crusher developed for this purpose was the same double-roll type used to crush fertile particles, but with different roll diameters. Some difficulties were encountered in flame hardening the crushing surfaces of the four crusher rolls (including two spares) to the desired hardness of $R_{c} 58$ to $R_{c} 60$. Figure 7 shows the results obtained by flame hardening the process control and production control specimens. The latter were processed along with the crusher rolls after the correct processing parameters had been verified with the process control specimens. It can be seen from the figure that process control specimen A was not hard enough, but the situation was corrected and verified by specimen $B$. The hardness of production control specimens 2 and 6 was at or above the desired minimum hardness of $R_{c} 58$ to the required depth of $1.78 \mathrm{~mm}(0.070$ in.). Specimen 4 retained the desired hardness to an acceptable depth of $1.27 \mathrm{~mm}$ (0.050 in.).

Inspection of the finished rolls by a dye penetrant technique revealed the presence of fine, intermittent, small circumferential cracks at a common location at the identical end of two of the four rolls purchased. The rolls were accepted for installation af ter consideration of the crack severity and location and the anticipated roll service. The crushing surfaces of the four rolls were scanned using a surface analyzer, and the surface profiles and surface finishes were documented for future comparative wear determinations.

Problems encountered during construction required imposing $100 \%$ inspection on a11 parts of the assembly. Substantial reworking of components was necessary to obtain hardware built to engineering specifications. 


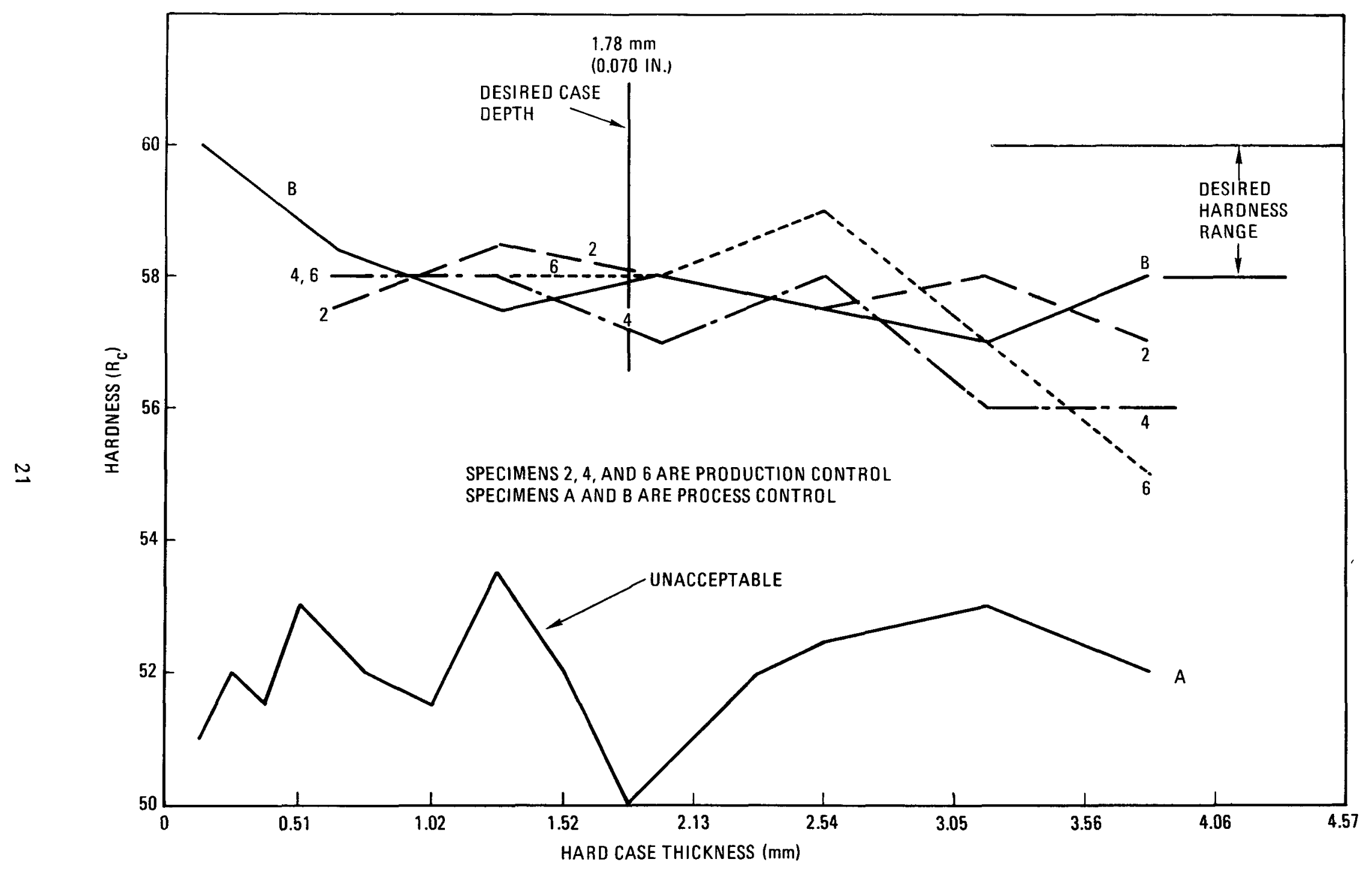

Fig. 7. Effect of flame hardening on process control and production control specimens 


\subsection{DEVELOPMENTAL TESTING}

Phase II testing of the fuel fissile particle crusher was successfully completed. The nominal roll crusher gap required to maximize both crushing efficiency and crushed particle size was $250 \mu \mathrm{m}(0.010 \mathrm{in.})$.

When initially received, the roll crusher nominal gap was $230 \mu \mathrm{m}$ (0.009 in.). This was changed to a nominal $330 \mu \mathrm{m}(0.013 \mathrm{in.})$ gap for the first crushing tests by switching appropriate rolls. A 200-g sample of FSV fissile particles (see Fig. 8 for size distribution) was processed at that time. Approximately $50 \%$ of the particles were uncrushed; therefore, a smaller roll gap [280 $\mu \mathrm{m}$ (0.011 in.)] was assembled.

At this gap setting, a study was done on the rotating roll torque versus roll gap to establish the correlation between radial bearing preload and the crushing gap between the rolls. The radial preload of a tapered roller bearing is created by the relative axial position of the inner and the outer bearing elements or races acting on the conical surfaces of the tapered rollers. The amount of radial preload is increased as the two races are brought more closely together. In the particle crusher, these relative positions are regulated by shims which position the outer bearing race. Thinner shims produce higher preloads.

During this study, shim thicknesses were varied 25 or $50 \mu \mathrm{m}(0.001$ or 0.002 in.) and the bearing preloads were measured by rotating each independent roll in the assembled crusher at a constant speed using a calibrated torque wrench and noting the rolling torque. The roll gap was gauged by manually roll-reducing a solld, tin-lead soft solder wire [Sn-60, 787 $\mu \mathrm{m}$ (0.031 in.) diameter]; accurately measuring the resultant ribbon thickness in three places; and averaging the results.

Figures 9 and 10 show the results of the preload study for each of the rolls in the crusher assembly. It should be noted in each figure that a rolling preload torque of 0.92 to $1.04 \mathrm{~m}-\mathrm{kg}$ ( 80 to $90 \mathrm{in.}-1 \mathrm{~b}$ ) is required 


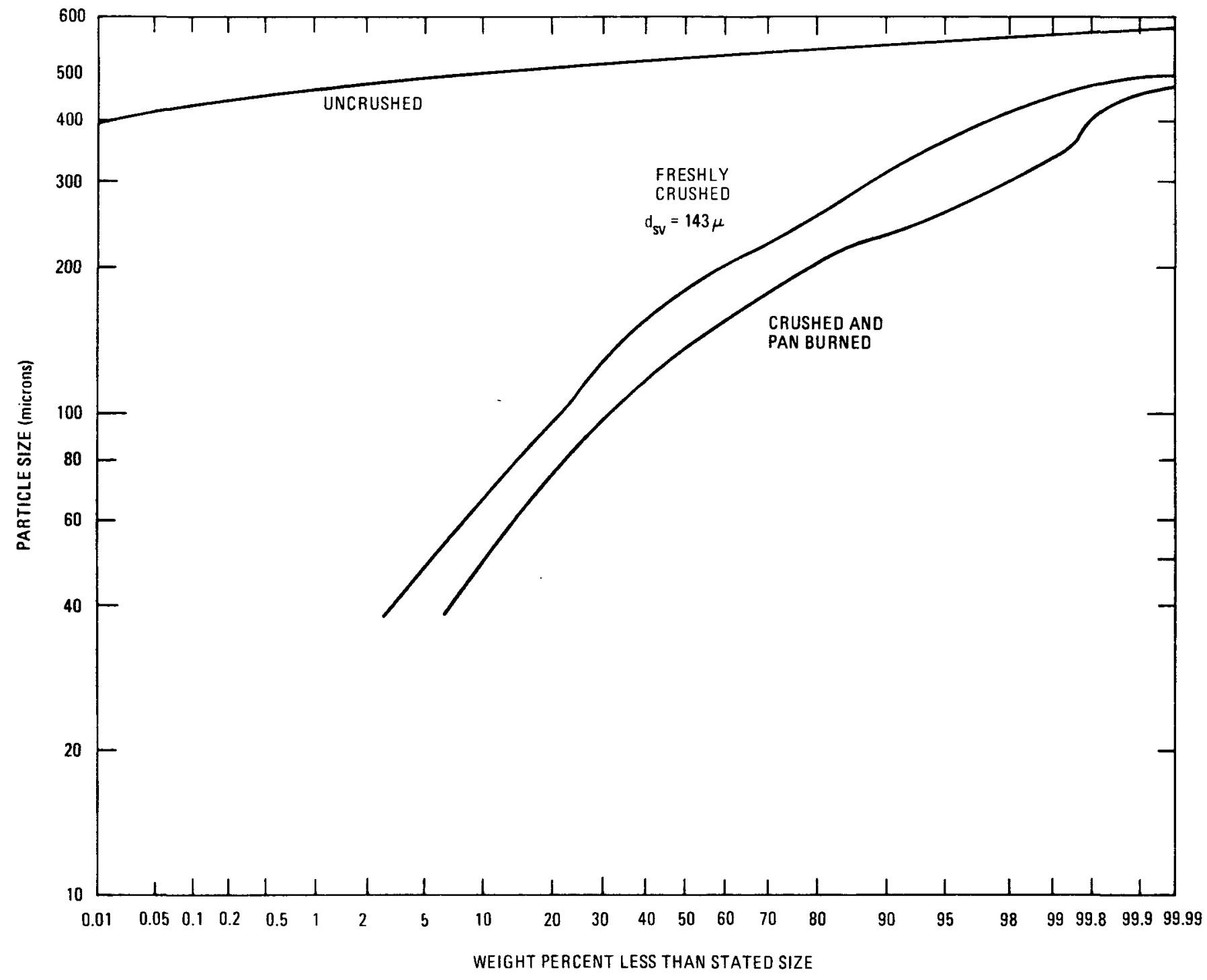

Fig. 8. Feed and product size distributions, FSV fissile particle crusher 


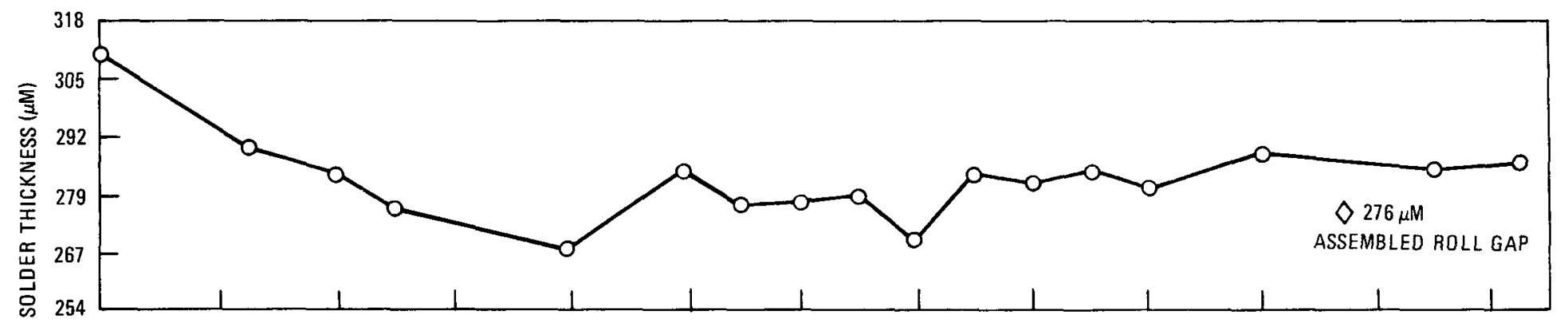

N

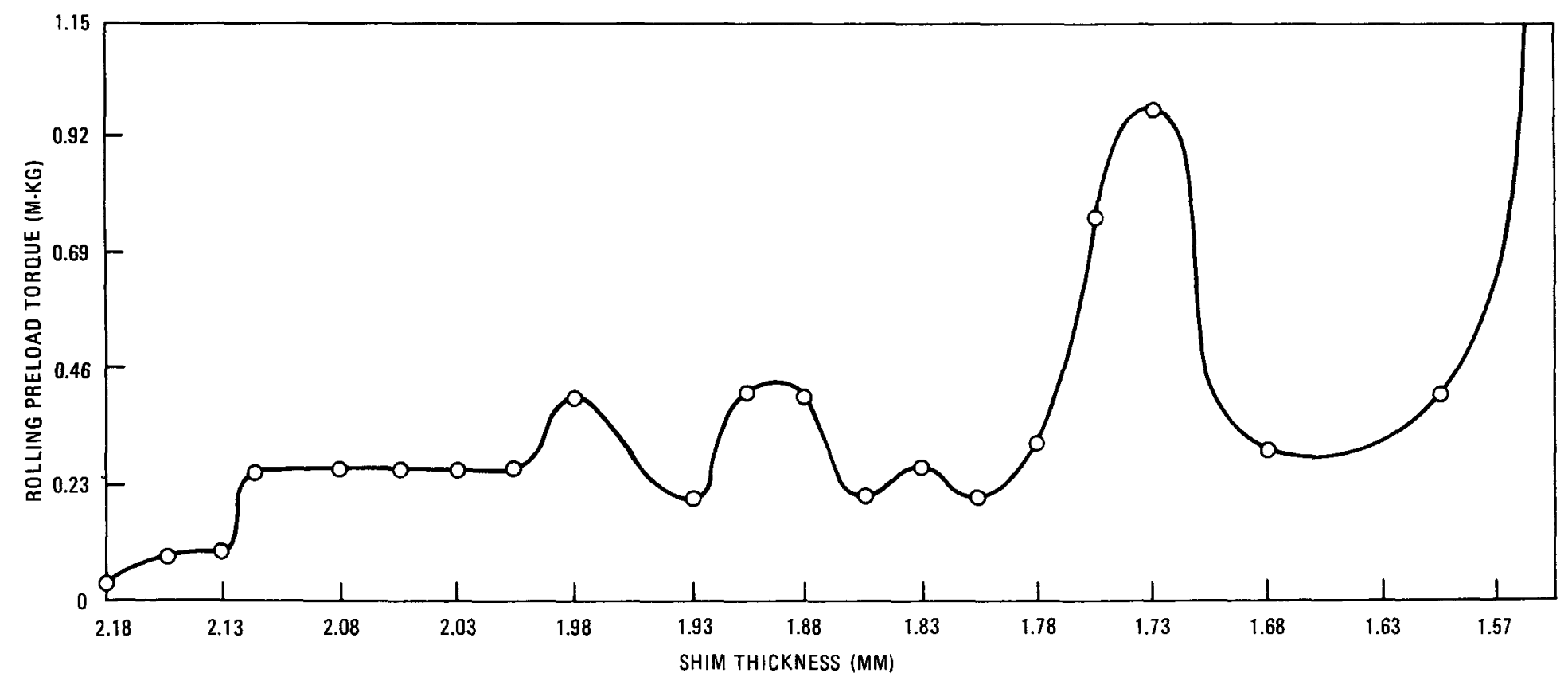

Fig. 9. Preload torque and solder thickness versus shim thickness, rol1 5211011-13, S/N 4340-5 

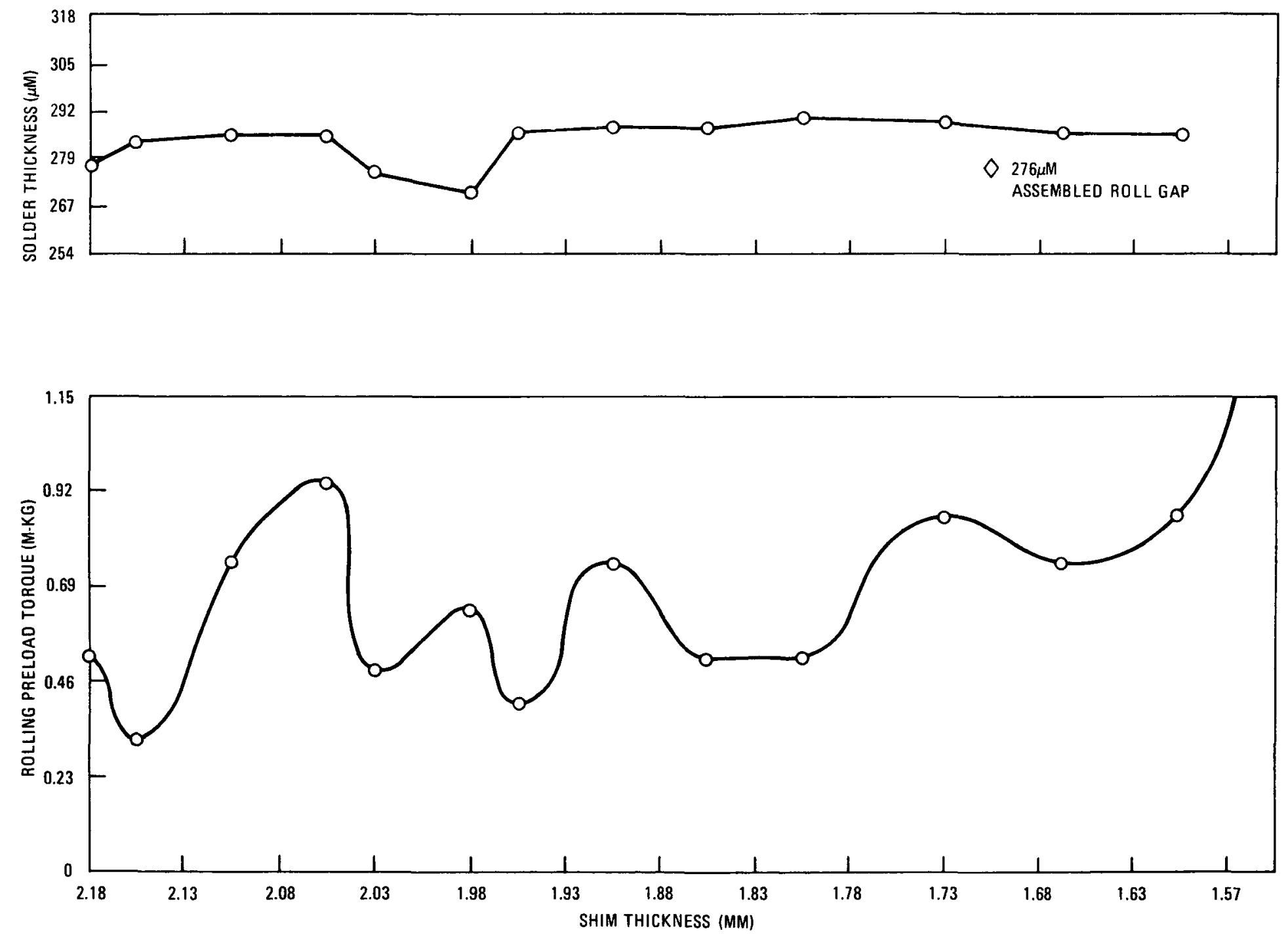

Fig. 10. Preload torque and solder thickness versus shim thickness, roll 5211011-10, S/N 4340-2 
to eliminate variances in the preload created by bearing seating, etc. However, viewing the changes in solder thickness with shim thickness, it would appear for both rolls that a preload of $0.26 \mathrm{~m}-\mathrm{kg}$ (40 in.-1b) torque* would produce a constant and consistent roll gap of from 280 to $292 \mu \mathrm{m}(0.0110$ to 0.0115 in.). The preload selected for future particle crushing was 1.04 m-kg (90 in.-1b). This proved to be too high for satisfactory bearing life.

Referring to Figs. 9 and 10, it can be seen that repeatable roll gap measurements were made using proper preload shimming and $787 \mu \mathrm{m}$ (0.031 in.) diameter solid solder. These gap measurements were consistent to within $13 \mu \mathrm{m}(0.0005 \mathrm{in.})$ and were only 13 to $18 \mu \mathrm{m}$ (0.0005 to $0.0007 \mathrm{in.})$ higher than the crusher roll gap calculated from inspection data for this crusher.

A 100-g sample of FSV fissile particles was processed yielding about $3 \%$ uncrushed particles. The roll gap following crushing was again $280 \mu \mathrm{m}$ (0.0110 in.) using the solder strip. Thicker solder [3302 $\mu \mathrm{m}(0.13 \mathrm{in.})]$ was then used. This was extruded to $330 \mu \mathrm{m}$ (0.013 in.). Since the smallest fuel particle was $300 \mu \mathrm{m}$ ( $0.0116 \mathrm{in.})$ and about $3 \%$ were uncrushed, it is reasonable to assume that the gap during highly loaded crushing conditions is greater than the $280 \mu \mathrm{m}$ (0.0110 in.) measured with the sma11 solder strip. The large solder strip results tend to confirm this, as the larger strips are a definite load on the rolls when extruded through the rolls.

The rolls were again changed to yield a nominal $250 \mu \mathrm{m}(0.010 \mathrm{in.})$ gap. The roll torque was adjusted to $1.04 \mathrm{~m}-\mathrm{kg}(90 \mathrm{in} .-1 \mathrm{~b})$. The gap as measured by the $787 \mu \mathrm{m}(0.031 \mathrm{In.})$ solder was $250 \mu \mathrm{m}(0.010 \mathrm{in}$.) while the thicker $3302 \mu \mathrm{m}$ (0.13 in.) solder ylelded a $305 \mu \mathrm{m}(0.012 \mathrm{in.})$ gap. The resulting crushing efficiency with $200 \mathrm{~g}$ of particles was $100 \%$.

The size distribution of these fully crushed FSV fissile fuel particles is shown in Fig. 8. The product angle of repose was $43^{\circ}$. The bulk density was $1.4 \mathrm{Mg} / \mathrm{m}^{3}$ and the tap density was $1.8 \mathrm{Mg} / \mathrm{m}^{3}$. The

*This was subsequently verified by the bearing manufacturer. 
throughput of the material was $80 \mathrm{~kg} / \mathrm{h}$ at $43 \mathrm{rpm}$ roll speed. Start under load was achieved. Normal power draw at $43 \mathrm{rpm}$ roll speed with choke feed conditions is $522 \mathrm{~W}$.

A burner run will be made on the $0.10-m$ secondary burner using FSV fissile particles processed through the roll crusher using a nominal 250-um roll gap.

\subsection{DEMONSTRATION OF LHTGR WAR FISSILE FUEL PARTICLE CRUSHING}

Phase III fuel particle crushing was successfully completed using weak acid resin (WAR) type TRISO coated fissile fuel particles burned back to the SiC coating. Depleted uranium was used in the manufacture of these fue1 particles as they were made in the developmental fuel production pilot plant. The particles contained $22 \% \mathrm{UC}_{3} \mathrm{O}_{0.5}, 32 \%$ carbon, and $46 \% \mathrm{SiC}$.

The size distribution is shown in Fig. 11. Inspection of Fig. 11 shows that about 6 wt \% of the fuel particles are less than $500 \mu \mathrm{m}(0.0197$ in.) in diameter. Previous experience has shown that setting the roll crusher gap slightly larger than the smallest particles to be crushed will result in high crushing efficiencies ( $>99 \%$ ) while minimizing overcrushing. A roll pair was available to give a 495- $\mu \mathrm{m}$ (0.0195-in.) roll gap, as measured by the 3175- $\mu$ m (0.125-in.) solid solder technique. Using this gap gave $100 \%$ crushing efficiency, with a size distribution after crushing as shown in Fig. 11. The crusher roll speed was $36 \mathrm{rpm}$ with $250 \mathrm{~W}$ required by the motor during crushing. The material throughput was $920 \mathrm{~g} / \mathrm{min}$.

Pertinent properties of the crushed particles were as follows: angle of repose $22^{\circ}$, bulk density $1.1 \mathrm{Mg} / \mathrm{m}^{3}$, and tap density $1.4 \mathrm{Mg} / \mathrm{m}^{3}$.

The material was then tray-burned in a muffle oven to burn away the carbon inner coatings and to convert the uranium to $\mathrm{U}_{3} \mathrm{O}_{8}$. Size analysis after tray burning is shown in Fig. 11. The material properties were: angle of repose $34^{\circ}$, bulk density $1.3 \mathrm{Mg} / \mathrm{m}^{3}$, and tap density $1.6 \mathrm{Mg} / \mathrm{m}^{3}$. 


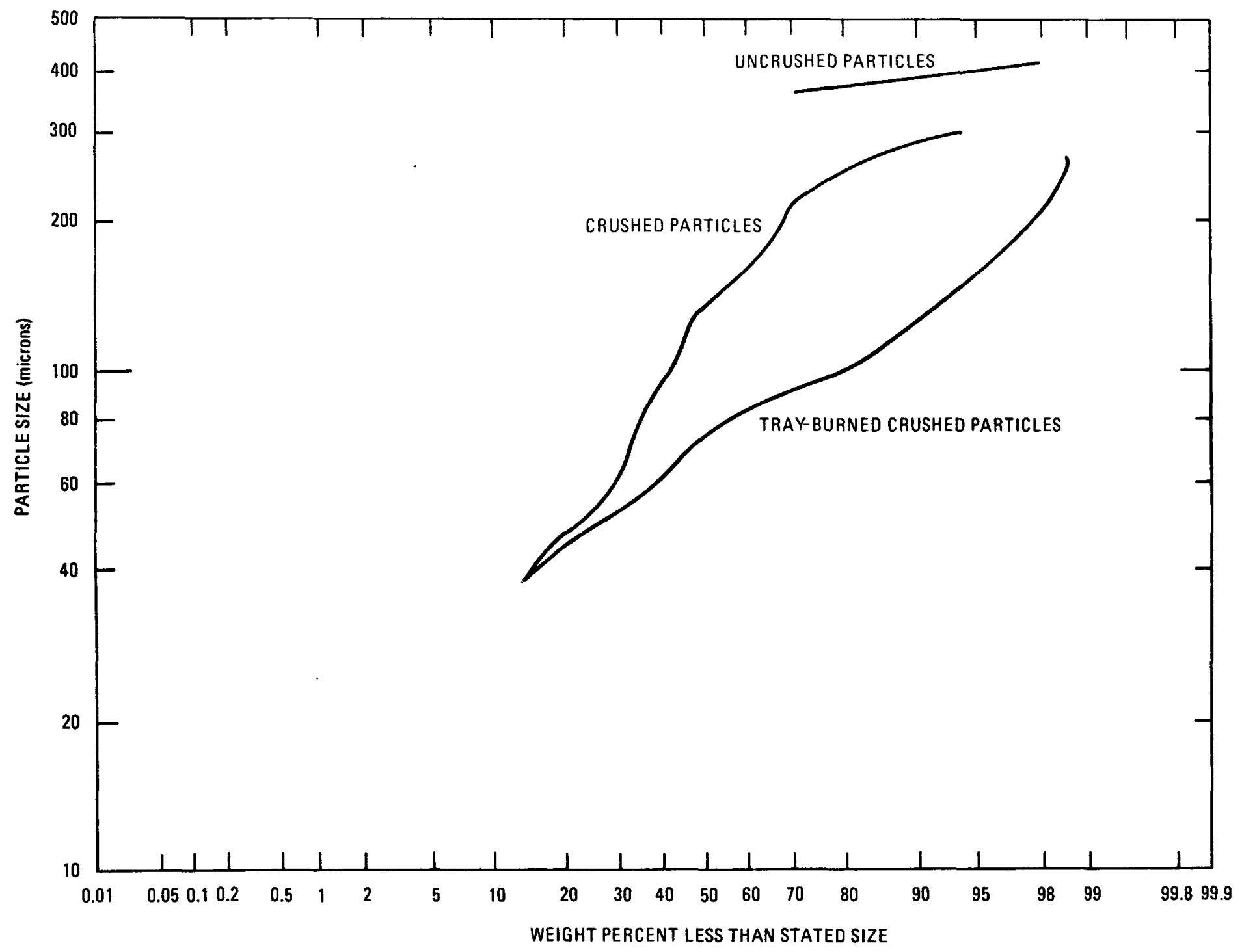

Fig. 11. Size distributions, crushed WAR particles 
No inert gas was used or needed during the crushing tests. A slight warming of the material was noted initially (about $5^{\circ} \mathrm{C}$ ), but this heat soon dissipated.

Start under load was achieved with $100 \mathrm{~g}$ of fuel particles.

Burning tests of crushed WAR particles in the $0.10-\mathrm{m}$ secondary burner were completed prior to the end of the fiscal year. No problems are foreseen in handling the material as processed by the roll crusher. The high SiC content ( $46 \%$ as compared to $22 \%$ for FSV fertile particles) will add a large degree of safety to the burner operation since it serves as inert fluidizing media.

\subsection{CRUSHER OPERATION - SEQUENTIAL BURN}

Twenty LHTGR-type fuel elements were used in a sequential operation of the pilot plant systems. These elements were (1) crushed in the fuel element size reduction system, (2) the graphite was burned of $f$ in the primary burner, (3) the remaining fuel particles were classified in the zig-zag pneumatic classifier, and (4) a portion of the classifier TRISO fissile stream was processed through the particle crushing and secondary burning stages. This provided feed for each of the systems which was typical of that produced in a pilot-plant operation. Previously, feed materials were specially made for each system, and they may or may not have been processed through the previous systems.

As part of the sequential pilot plant operations, $49.3 \mathrm{~kg}$ of TRISOcoated WAR particles and $9 \%$ fuel element graphite were crushed and burned in the $0.20-\mathrm{m}$ secondary burner system. The fissile fraction of classified primary burner product was used as feed for the fertile roll crusher. Material weight was $49.3 \mathrm{~kg}$. Composition was 9 wt \% carbon, 6 wt \% $\mathrm{ThO}_{2}$, and 85 wt \% TRISO WAR particles. This material was fed through the doubleroll crusher to yield a crushed feed size distribution as shown in Fig. 12. 


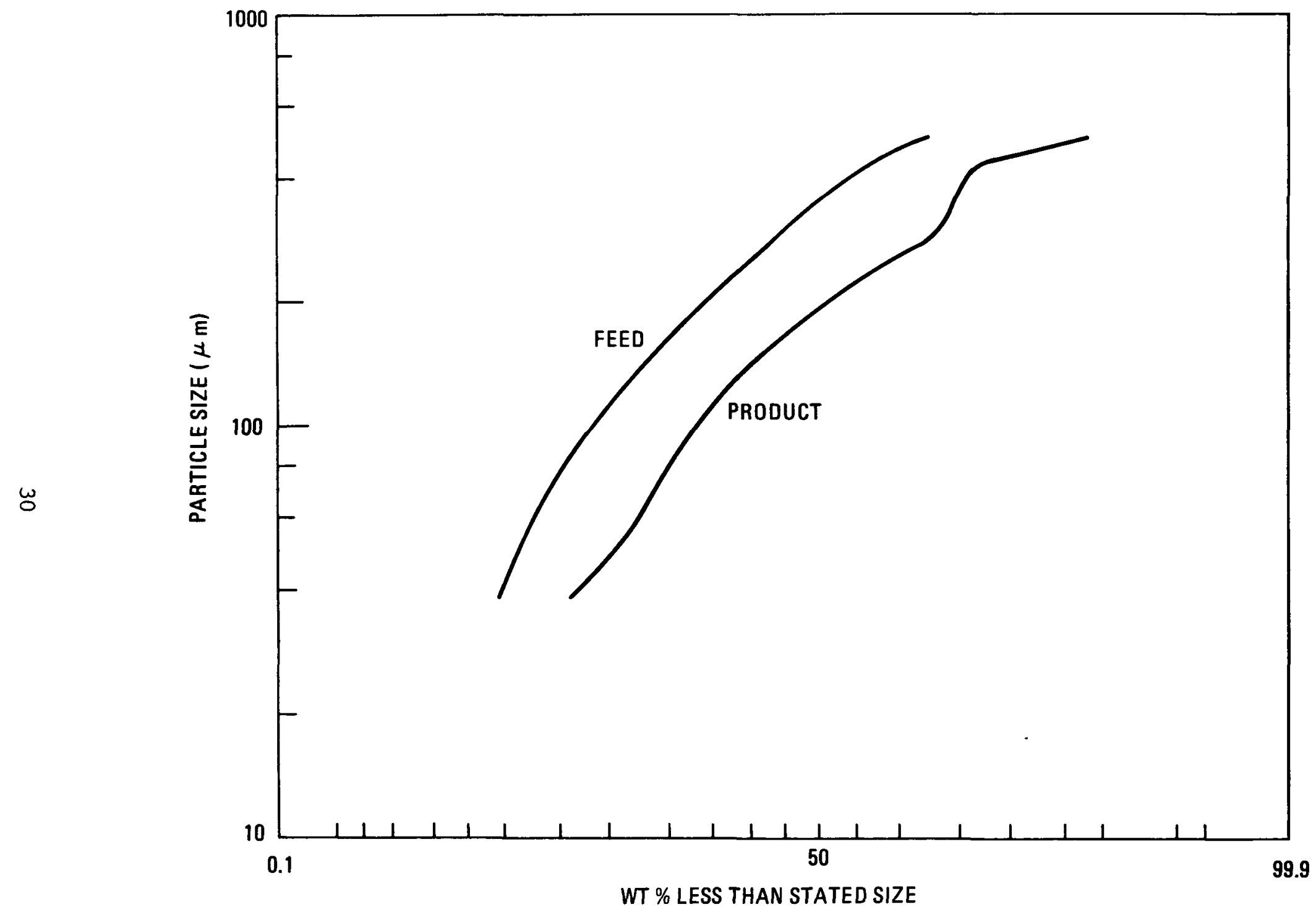

Fig. 12. Size distribution of feed and product from sequential operation run using 0.20 -m secondary burner 


\section{CRUSHER DRIVES AND BEARINGS}

Drives in the particle crushers were powered initially by direct current electric motors to permit varying motor speeds and changing the crushing rates, thus establishing the relationship between roll speed and crusher efficiency. From these tests, a single operating speed could be determined for particle crushing. Power calculations using then-known data were compared with prior test results and power demands on similar equipment. It appeared that a 560-W $(3 / 4-\mathrm{hp})$ drive motor would be satis-

factory. Due to the many uncertainties in the calculations, however, provisions were made to permit upgrading the drive to $746 \mathrm{~W}$ ( $1 \mathrm{hp}$ ) by simply replacing the $560-\mathrm{W}(3 / 4 \mathrm{hp})$ motor with the more powerful unit.

Early in the testing, the crusher drive motor created problems by stalling. The cause was attributed to crusher manufacturing inaccuracies. Later, a roll, bearing overheated, which caused the motor to overheat and stall. The bearing was found to be low on grease. After cleaning and regreasing, the bearing functioned for the remainder of the run, but was in poor condition. The unit was carefully disassembled, and assemblies and components were examined for evidence of fallure, wear, or other defects. Two bearings were selected and forwarded to the bearing manufacturer's laboratories for analysis of wear and general condition. Grease samples from each bearing were tray-burned in a muffle oven to remove all hydrocarbons, graphite, and fuels, and to expose any metallic and silicon carbide residuals. Finely divided foreign material in varying amounts was found in the bearing grease. Thus there existed a potential for accelerated bearing wear, overheating, and eventual failure. The bearing manufacturer later confirmed that apparently the silicon carbide dust did get into the bearings, causing excessive wear, which, coupled with an unnecessarlly high bearing preload, contributed to the bearing overheating. Their recommendations were to improve the sealing for the bearings to exclude the dust, and to reduce the bearing preload by at least one half [to $0.51 \mathrm{~m}-\mathrm{kg}$ ( 45 in.-1b) torque]. 
The crusher was reassembled using two replacement bearings. Care was exercised not to overlubricate, which reduces bearing efficiency. The bearing shafts were preloaded to $0.81 \mathrm{~m}-\mathrm{kg}(70 \mathrm{in.}-1 \mathrm{~b})$. (The manufacturer's recommendation of $0.51 \mathrm{~m}-\mathrm{kg}(45 \mathrm{in.-1b})$ was recelved after reassembly.) $\mathrm{A}$ 746-W (1-hp) dc drive motor was obtained to replace the 560-W (3/4-hp) drive and to furnish more power and avert stalling. The crusher was placed into service crushing feed for the secondary burner runs.

From continued operation and testing of the particle crusher, it was determined that the installed 746-W (1-hp) drive was not sufficiently reliable for prototypical operation. It was observed to be incapable of starting under a full load of product and to stall out when product was discharged to the crusher while it operated under no-load and full operating speed conditions.

The drive requirements for the particle crusher were recalculated to include new and conservative torque values for the passive particle load, crushing work, and active maximum bearing preloads. Since the particle crusher operates at a single speed, a variable speed drive was not needed and the drive was changed to an ac squirrel-cage induction motor, NEMA Class B. With constant speed roll operation, an ac motor is a better drive choice since it operates best at a single speed. The standard squirrelcage induction motor (NEMA Class B) has operating characteristics that are attractive to the crusher drive. These motors will deliver two to twoand-one-half times the operating torque at start for start-under-load conditions, and the torque rises sharply with modest decreases in speed from full operating speed (when the load is applied, the speed decreases and the stall torque rises). The ac motors are also smaller and 1ighter than their dc counterparts, and have simplified electrical controls.

To provide an estimation of the power requirements, the particle column load, the work of crushing, and the bearing preloads were considered. This indicated the need for a 1492-W (2-hp) drive at the roll speed of 40 rpm. A new single speed ac electric motor and reducer were purchased, 
adapted, and installed in the system. This new arrangement cannot be fully tested beyond the simple initial testing until the sequential burner runs are performed.

During the refitting of the crusher to a more powerful drive, two of the bearing installations were modified to provide improved dust seals. One modification included the installation of Nilos seals on both bearings. The Nilos seal is a metallic membrane located between the inner race and the roll shoulder and seals by spring-loading on the outer race. This puts two mechanical seals in the path of influxing debris. The mounting of one Nilos-equipped bearing was altered to permit the introduction of a positive gas purge, presenting another obstacle to entry of dust into that bearing. One crusher is now equipped with two bearings sealed by single seal rings, a single bearing with a Nilos second seal, and a similar double sealed bearing with a positive gas purge. The efficiency of these improved sealing arrangements will be evaluated after sequential test runs.

The dimensional checks of the crusher parts and assemblies performed during retrofitting to the larger motor revealed numerous discrepancies, which, wherever possible, were corrected prior to reassembly. However, it was discovered that the parallelism of the side body assemblies could be disturbed by the pressure exerted from preload torquing the bearings in place. This was possible by the manufacturing tolerances between the pins and holes aligning the side bodies with the end bodies. A spacer bar was designed to prevent the inward and outward motion of the side bodies, which ensured the maintenance of precise parallelism while preloading the bearings. These spacers were installed prior to the 1atest assemb1y of the crusher. 


\section{ROLL WEAR}

The crusher rolls for the particle crusher are periodically removed, decontaminated, and examined for evidence of wear. The roll surfaces were inspected using a recording surface analyzer, which scans the surface for roughness and contour change. Ro11 diameters were measured in 20 places and compared with previous measurements. Photographs were taken of interesting surface sites for comparison with previously made pictures.

The crushing surfaces of the hardened AISI 1018 roll and the AISI 4340 roll were very similar in appearance at each observation after the adherent graphite and carbon coating had been removed with emery paper. Both roll surfaces contained numerous unidentified anomalies, which appeared as clustered pits. These anomalies and the nominal roll surfaces were scanned with a brush surface analyzer for roughness, depth of pits, grooves, etc., and pitted areas were explored.

Initially, the roll surface roughness increased from RMS 16 to RMS 28, and then appeared to stabilize. The depths of the pits remain unchanged although the pit breadths are apparently increasing, as might be expected. Some of these changes may be attributed to the hand scouring of the roll crushing surfaces with emery paper to remove surface contamination.

The crushing surfaces of both rolls at the ends have become slightly burnished but still possess sharp, unbroken edges. The pitted areas are typically relatively shallow $[<0.051 \mathrm{~mm}$ ( $<0.002 \mathrm{in.}$ ) deep] although quite wide [5.1 mm (0.20 in.)] and rough (RMS 112), for example. The reasons for these pitted regions are unknown, and efforts are continuing to determine them. 
Using successive photographs of the pitted regions of the roll surfaces, certain interesting sites have been identified and compared. The characteristics of the sites have remained virtually unchanged, and the sites are readily located and identified.

The results of roll examination to date indicate no positive definable trends in wear of the roll crushing faces from the crushing of the siliconcarbide-coated fuel particles. There are no identifiable differences between the carburized and hardened AISI 1018 roll and the surfacehardened AISI 4340 roll. 


\section{FUTURE PLANS}

The test program for the fuel particle crusher called for the performance of experimental work to ascertain that the crusher achieved the design objectives in the design criteria (Ref. 3), and provided data and observations identified in the activity plan (Ref. 2).

The double-roll crusher with a fixed crushing gap performed as expected during testing and met the design requirements. As a result of crusher operations, certain modifications and alterations to the design have been indicated as follows:

1. Reduce manufacturing and assembly complexity and cost by using a new housing design.

2. Increase the wear life of the roll end plates by selective hardening or other means.

3. Provide thermal expansion capability, simplify the bearing preloading, and assure improved reliability by using a modified bearing design.

4. Increased bearing protection by introducing improved bearing seal methods.

5. Assure restart capability when fully loaded and avert stalling under a rapidly applied full load by upgrading the drive system.

6. Extend roll wear life by altering the roll hardness, materials, or heat treatment. 
Each of these topics has received initial attention during particle crushing for burner operations, except for the new housing design, bearing changes, and roll alterations to improve wear life.

Future planning calls for a complete design evaluation of the existing particle crusher to assess its suitability as a prototype to the HRRF, and to recommend alternatives to the existing design, where needed.

Subsequently, the fuel particle crusher will be completely redesigned to reflect recommendations arising out of the design evaluation and the continuing operation of the crusher. The effectiveness of the current upgrading of the drive system to a higher horsepower ac system, of purged and shielded bearings, and of implanted ceramic wear rods in the crusher side plates will be evaluated as the data become available. These changes will be incorporated into the crusher redesign, where appropriate. A new test program for evaluation of the new design will then be devised and the equipment proof tested. 


\section{ACKNOWLEDGMENTS}

The authors wish to thank E. J. Cook and W. S. Rickman for their participation in the testing of the crushers. Since most of the staff technicians in the Operations Branch of the Recycle Development Department participated in the tests and sampling, thanks is due them all for their helpfulness. 


\section{REFERENCES}

1. Baer, J. W., et al., "Interim Design Report: Fuel Particle Crushing," DOE Report GA-A14675, Genera1 Atomic Company, November 1977.

2. "Activity Plan - Fuel Particle Crusher," General Atomic Company, unpublished data.

3. "Design Criteria - Fuel Particle Crusher," General Atomic Company, unpublished data.

4. Kunii, D., and 0. Levenspiel, Fluidization Engineering, John Wiley \& Sons, Inc., New York, 1969.

5. "Operating Procedure - Secondary Burner," General Atomic Company, unpublished data. 